\title{
The Effects of Export Expansion Policy in Poland in the Context of Recommendations of Global Organizations
}

\author{
Zofia Wysokińska \\ Ph.D., Full Professor at the University of Lodz \\ Faculty of Economics and Sociology \\ Department of World Economy and European Integration, Lodz, Poland \\ e-mail: zofia.wysokinska@uni.lodz.pl
}

\begin{abstract}
The aim of this paper is to present the results of an analysis and evaluation of the implementation of one of the tasks of the Strategy for Responsible Development (SRD) until 2020 (with a perspective up to 2030), adopted in Poland, which should increase Poland's foreign expansion.

The paper attempts to present these results in the context of diagnoses, forecasts and recommendations (developed by experts of global organizations) regarding macroeconomic policy directions for the coming years recommended for member countries of such organizations as the International Monetary Fund, the World Bank Group, the OECD and UNCTAD/UN.
\end{abstract}

Keywords: Strategy for Responsible Development, foreign expansion of Poland, recommendations of global organizations, macroeconomic policy

JEL: $\mathrm{O} 13$ 


\section{Introduction}

In this paper, a research question was posed. It asks whether and to what extent an adjustment has been made to the recommendations for macroeconomic policies of governments - presented in the reports of such global institutions as the International Monetary Fund, World Bank Group, OECD, UNCTAD/UN - in one of the pillars of the Polish government's program, in place since 2016, which is the foreign expansion of Poland. The reports of these organizations include recommendations for all groups of countries, i.e., highly developed countries, developing countries and countries in transition. The most important recommendations include:

- Focusing on the dynamic development of international trade and recognizing its positive impact on growth, especially in those countries that have lagged too far behind in recent years in relation to their potential;

- Actions aiming to improve productivity indicators (of production factors), the low growth of which contributed to the stagnation of income;

- Inclusive policies addressing the growing inequalities which have resulted, to a large extent, from very rapid technological change;

- Actions ensuring gender equality, so that the global economy can use its full potential;

- Debt management, which should help underdeveloped countries and countries in transition to adapt to both lower (than in previous years) revenues from raw materials and to the process of restructuring their economies by taking on new challenges.

Then the paper analyzes and assesses to what extent Poland has applied the recommendations of experts from global institutions in its socio-economic policy, especially with regard to increasing the dynamics of trade with foreign countries, including the share of more-processed goods (focusing on export expansion and on the diversification of export and import) as well as to the reduction of the scale of social exclusion.

In the future, it seems necessary to focus on larger export expansion. However, it requires increasing the role of e-commerce in accessing foreign markets by creating internet platforms to ensure access to the global market for the SME sector and the use of the huge potential of well-educated Polish IT specialists and foreign students studying in our country.

The good forecasts for the global economy for the coming years create such a chance if the new technologies (in particular, in the field of ecology and low-emission technologies) are used, and existing barriers (especially administrative and legal ones) for the development of small and medium-sized companies in their export activities are removed. 


\section{Diagnoses of the condition of the global economy and its development forecasts as well as recommendations for the macroeconomic policy of government institutions in the light of the opinions of experts from selected global organizations}

\section{Diagnosis and forecast of the International Monetary Fund}

Experts from the IMF state that increased trade integration (mainly caused by the liberalization of world trade) contributed to economic growth in developed and developing countries in the second half of the twentieth century. International trade played a key role in stimulating global growth, thus contributing to unprecedented progress in terms of productivity and living standards. This made it possible to lift millions of people out of poverty and to reduce prices. However, the pace of development of trade, productivity and income growth has gradually decelerated since the early 2000s. This trend partly contributed to the slowdown of economic growth, especially after the 2008 global financial crisis. The increase in productivity (of production factors) sharply slowed down, which contributed to the stagnation of income in many developed economies and, consequently, caused political opposition to globalization. The slowdown of global trade is another long-term effect caused by a slowdown of productivity. As a consequence, trade has barely kept up with global GDP since 2012. In order to solve the problems that contribute to the decline in productivity, it is recommended that decision-makers focus on strengthening innovation and improving education, accelerating structural reforms and taking actions to counteract the crises.

Due to the growing inequality in the distribution of income, it is estimated that trade has had a negative impact on some groups of employees and entire communities, especially in Europe and the United States. These dislocations, which also reflect the impact of technological innovation, were reflected in slower economic growth and the resulting reactions weakened the support for global economic integration. ${ }^{1}$

Among the actions to be taken, the IMF recommends:

- Increasing demand where it is weak, especially in the area of investment, through carefully selected public investment and removing obstacles to private investment. This gives hope for an increase in capital accumulation and investment in the development of new technologies.

1 International Monetary Fund, Annual Report 2017, Promoting Inclusive Growth, https://www. elibrary.imf.org/doc/IMF011/23917-9781475563252/23917-9781475563252/Other_formats/ Source_PDF/23917-9781484306123.pdf; pp. 6-16; https://www.imf.org/en/ Publications/WEO/ Issues/2017/07/07/world-economic-outlook-update-july-2017, pp. 1-7 (accessed: 27.10.2018). 
- Restructuring corporate debt and strengthening banks' balance sheets in order to facilitate access to loans and stimulate investments in physical and intangible capital.

- Ensuring that governmental institutions send clear signals about the directions of future economic policy, in particular with regard to fiscal, regulatory and trade policy, as this will help support investments.

Experts also state, however, that after a few years of low growth, the world economy has begun to gain momentum. Emerging markets and some low-income developing countries have experienced economic growth as part of a cyclical recovery. Most importantly, there was again an increase in employment in many economies. However, this good news is accompanied by uncertainty about the future of the global economic and financial order. IMF members have faced a number of challenges, and in 2017 they focused on solving urgent global problems. The importance of the following issues has been emphasized:

- First of all, international trade and its positive impact on growth, especially in the countries that have lagged too far behind;

- Productivity (of production factors), the low growth of which contributed to the stagnation of income;

- Inclusive social policies addressing growing inequalities caused, to a large extent, by very rapid technological changes;

- Gender equality, so that the global economy can use its full potential;

- Debt management, in order to help underdeveloped countries adapt to lower income from raw materials and to help them restructure their economies by taking on new challenges. ${ }^{2}$

The IMF experts have increasingly focused on:

- The positive influence of trade on the trends in the labor market.

- Making trade a driving force for all countries.

- Creating an appropriate economic policy, including trade policy, aimed at better adjustment processes, so that all countries can benefit from trade and thus strengthen the global economy. ${ }^{3}$

The International Monetary Fund, in its forecasts regarding the growth of the Global GDP for 2017-2018, predicted that the global economy is going to develop at a rate of $3.7 \%$. The estimates for Japan, China, European emerging markets (including Poland) and Russia were revised upwards. The reduction of expectations affected the United States, Great Britain and India. The International Monetary Fund predicted that the GDP growth in Poland would amount to $3.8 \%$ in 2017 and to $3.3 \%$ in $2018 .{ }^{4}$

2 IMF, Annual Report 2017, op. cit.,

3 Prepared on the basis of: https://www.imf.org/en/Publications/WEO/Issues/2017/07/07/ world-economic-outlook-update-july-2017.- IMF Annual Report 2017, Part I , Overview (accessed: 3.11.2018).

4 As above. 
In fact, it reached a higher level of 4.6\% in 2017, and the forecasts for 2018 predict approx. $5 \% .^{5}$

The steady expansion of the world economy, under way since mid-2016, continues, with global growth for 2018/19 projected to remain at its 2017 level. At the same time, however, the expansion has become less balanced and may have peaked in some major economies. Downside risks to global growth have risen in the past six months and the potential for upside surprises has receded. Global growth is projected at 3.7 percent for 2018-2019 - 0.2 percentage points lower for both years than forecast in April. ${ }^{6}$ In the United States, momentum is still strong as fiscal stimulus continues to increase, but the forecast for 2019 has been revised down due to recently announced trade measures, including the tariffs imposed on $\$ 200$ billion of US imports from China. Growth projections have been marked down for the euro area and the United Kingdom, following surprises that suppressed activity in early 2018. Among emerging markets and developing economies, the growth prospects of many energy exporters have been lifted by higher oil prices, but growth was revised down for Argentina, Brazil, Iran, and Turkey, among others, reflecting country-specific factors, tighter financial conditions, geopolitical tensions, and higher oil import bills. China and a number of Asian economies are also projected to experience somewhat weaker growth in 2019 in the aftermath of the recently announced trade measures. ${ }^{7}$

\section{Diagnosis and forecast of experts from the World Bank Group}

The World Bank Group experts predict that the growth rate of the global economy will increase to over $2.9 \%$ in 2018-2019, which is in line with earlier forecasts. Growth trends regarding global production and trade have strengthened, financing conditions have been favorable, and commodity prices have stabilized. It is expected that the growth rate in emerging markets and developing countries will increase to an average of $4.6 \%$ between 2018 and 2019. This improvement is stimulated by decreasing barriers to the activity of raw material exporters and a large increase in the activity of importers of goods. It was pointed out that emerging countries and developing countries should accelerate reforms to promote investment, trade and productivity.

Is also assessed that global trade has gained momentum after two years of apparent weakness. This growth is driven by the strengthening of investments in developed economies, increasing trade flows to and from China, and improving import demand in emerging markets and developing economies exporting raw materials. Neverthe-

5 According to the data of the Central Statistical Office.

6 The global growth was expected to tick up to a 3.9 percent rate in both 2018 and 2019; World Economic Outlook, April 2018, Cyclical Upswing, Structural Change, International Monetary Fund, p. XVI.

7 World Economic Outlook, Challenges to Steady Growth, International Monetary Fund, October 2018; https://www.imf.org/en/Publications/WEO/Issues/2018/09/24/world-economic-outlook-october-2018\#Full\%20Report; pp. XVI-XVII (accessed: 4.11.2018). 
less, slower trade liberalization, weakening integration of value chains and increased uncertainty about trade policy have increased uncertainty about medium-term development prospects. Raw material prices are expected to grow at a moderate pace although oil price forecasts have been revised downwards, reflecting the outlook for US oil and shale gas production growth. ${ }^{8}$

Currently, the declining markets of importers of goods and developing countries are characterized by stable growth, especially with regard to imports. The violent turmoil caused by the recent drops in prices is weakening and the adjustment policies in many countries, supporting domestic demand and the revival of global trade, "drive" the growth of export. The forecast for commodity imports growth is stable at an average level of 5.7\% in 2018-2019. The gradual transition of China to slower, but more sustainable growth is proceeding as expected.

Economic growth has a positive effect on low-income countries, as rising metal prices encourage production in a sector oriented towards the export of metals, and infrastructural investments are also continued in economies not dependent on raw materials. However, some low-income countries are still struggling with the decline in oil production, conflict, drought, insecurity and many political challenges. It is expected that growth in low-income countries will increase in 2017-2019 as a result of the activity of firms exporting goods.

Downside risks continue to dominate in the forecasts despite the possibility of a more expansionary fiscal policy in major developed economies. The escalation of trade restrictions could cause only a barely perceptible recovery in trade and contribute to a limitation of the gains from previous liberalization efforts. It is estimated that a downward reduction in oil prices may hinder the initial recovery in oil-exporting countries. In the long run, low productivity and low investment growth may further weaken the potential growth.

It is estimated, however, that the negative impact of the previous fall of commodity prices on public budgets in commodity exporter countries is gradually decreasing, but the fiscal space remains limited in many emerging and developing markets, suggesting the need for continued fiscal adjustments. Increased investment and productivity in emerging and developing markets gradually slowed down after the crisis, and reforms will have to be accelerated to improve growth prospects. Policy priorities include structural actions aimed at improving the business climate, supporting investment in human and physical capital, and strengthening regional and global trade integration of emerging markets and developing economies. Greater trade openness is generally associated with lower poverty in emerging and developing markets as well as with improvement of the status of these countries and their transition from low to medium income. ${ }^{9}$

8 The World Bank Global Economic Prospects: Highlights from Global Outlook: A Fragile Recovery, http://www.worldbank.org/en/publication/global-economic-prospects, pp. XVII-XVIII and findings of Chapter 1.

9 Elaborated on the basis of The World Bank Global Economic Prospects: Highlights from Global Outlook: A Fragile Recovery, as above. 


\section{Diagnosis and forecast of the OECD and UNCTAD/UN}

According to OECD experts, the global economic sentiment has improved over the last year. Investor confidence indicators, industrial production, main employment rates and cross-border trade flows have improved in most economies. This still small cyclical expansion does not seem to be sufficient to ensure a sustained increase in production potential or to reduce persistent inequalities between countries and within countries. Threats to finances may arise as a result of political and geopolitical shocks. In comparison with the 20 -year pre-crisis average, the growth of GDP per capita proved to be lower by more than 0.5 percentage points than initially expected, although the overall global growth rate should exceed $2.5 \%$ in 2018. Concluding, it was found that the global economic outlook is better, but not good enough to permanently improve the well-being of citizens. ${ }^{10}$

The OECD, however, in the latest edition of Economic Outlook, increased the forecast for economic growth for the world for 2017 by 0.6 percentage points, up to $3.6 \%$. The global GDP in 2018 should accelerate to $3.7 \%$, and then it is expected to slow down to $3.6 \%$ in 2019. A significant correction in plus was made by the OECD in relation to Poland. The OECD experts predict that the Polish economy will record an economic growth equaling $4.3 \%$ in that year, compared to the previously expected $3.6 \% .{ }^{11}$

In World Investment Report, Investment and the Digital Economy prepared by UNCTAD/UN, UNCTAD experts showed that the dynamic development of the digital economy has particularly important implications for investments, and investments are crucial for further digital development. ${ }^{12}$ The adoption of digital technologies can transform both the international activity of $\mathrm{MNEs}^{13}$ and the influence of their foreign branches in the receiving countries. Digital development in all countries, and especially the participation of developing countries in the global economy, requires a targeted investment policy. The importance of MNEs in the area of information and communication technologies (ICT) in international production has grown rapidly over the last five years. In 2010-2015, the number of technology firms in the UNCTAD ranking, belonging to the top 100 companies, more than doubled. The assets of those enterprises increased by $65 \%$, and operating revenue and employee income by about $30 \%$ in relation to the trends for the other 100 largest enterprises. The importance of digital MNEs, e-commerce and digital content platforms is also growing rapidly. ${ }^{14}$

10 Based on OECD - Economic Outlook, June 2017, by Angel Gurgia - Secretary General, Catherine L. Mann, OECD Chief Economist and Head of Economics Department, better, but not enough, OECD, Paris, 2017, executive summary and chapters $1 \& 2$ of the full report.

11 As above.

12 World Investment Report - Investment and The Digital Economy, 2017, pp. 13-14, https://unctad. org/en/PublicationsLibrary/wir2017_en.pdf (accessed: 5.11.2018).

13 MNEs - Multinational Enterprises.

14 World Investment Report - Investment and The Digital Economy, 2017, op. cit., pp. 10-14. 
There is a legitimate conviction that the digital economy creates new opportunities for trade and development. It helps smaller companies and entrepreneurs in developing countries to easily connect to global markets and opens up new ways to generate income. ICT, e-commerce and other digital applications are used to promote entrepreneurship, including the empowerment of women as entrepreneurs and traders, as well as to support production activities, attractive jobs, creativity and innovation. In addition, mobile and digital solutions contribute to facilitating financial integration. Small companies in developing countries provided with sufficient connectivity can have access to various in-cloud services and get financing on online platforms. ${ }^{15}$

Additionally, in another UN report, UNCTAD/UN experts point to the growing role of GAFAA ${ }^{\mathbf{1 6}}$ in world trade, believing that the growing control over future production processes in developed countries is becoming a subject of competitors' growing concern along with the growing monopolistic power of GAFAA. They are among the richest companies in the world. GAFAA are currently seen as stimulators that drive the future digital economy, but they also generate disruptions. Confronted with Google, Apple, Facebook and Amazon, based in the US, even European countries feel threatened by the shift of future digital power to the US and their governments have begun to think about regulations towards the US Internet giants, encouraging native companies to overtake GAFAA. ${ }^{17}$

\section{The results of Poland's export expansion as one of the tasks of the Government Program - Strategy for Responsible Development (SRD) until 2020 (with a perspective until 2030) adopted in Poland}

The aim of this part of the paper is to present selected results of the realization of one of the tasks of the Strategy for Responsible Development (SRD) until 2020 (with a perspective until 2030) adopted in Poland, two years after its implementation. One of the effects of the SRD is the export expansion policy.

The goals of the foreign expansion policy include:

— increasing the internationalization of the Polish economy,

— increasing exports of technologically advanced goods,

— increasing the degree of diversification of Polish export.

This part of the paper starts with a presentation of the changes in the geographic and product structure of Polish exports, with particular emphasis on the share

15 Information Economy Report 2017, Digitalization, Trade and Development, UNCTAD; https://unctad.org/en/PublicationsLibrary/ier2017_en.pdf; pp. XIII-XVI.

16 GAFAA (Google, Apple, Facebook, Amazon, Alibaba).

17 Rising product digitalization losing trade competitiveness -UNCTAD, 2017, http://unctad.org/ en/ PublicationsLibrary/gdsecidc2017d3_en.pdf, pp. 17-18 (accessed: 1.08.2018). 
of more-processed and technologically advanced goods as well as the impact of inflow and outflow of foreign investment to and from Poland on the changes in the economy in the last $2-3$ years.

Then, an attempt is made to assess whether and to what extent the Polish economic policy regarding the increase in internationalization has been part of the aforementioned global organization recommendations in recent years.

The tasks resulting from the Responsible Development Strategy include the following:

— improving Poland's competitive position in the global economy,

— increasing the value of Polish exports,

- greater geographical diversification of exports,

- improving the commodity structure of exports towards an increased share of more-processed goods, including high-tech goods.

When assessing Poland's position in global competitiveness rankings, it can be concluded that it improved from $38^{\text {th }}$ place in 2017 to $34^{\text {th }}$ in 2018 - see The 2018 IMD World Competitiveness Ranking) presented below.

Table 1. The 2018 IMD World Competitiveness ranking

\begin{tabular}{|l|c|c|}
\hline \multicolumn{1}{|c|}{ Country } & Position in 2018 ranking & Position in 2017 ranking \\
\hline USA & 1 & 4 \\
\hline Hong Kong SAR & 2 & 1 \\
\hline Singapore & 3 & 3 \\
\hline Netherlands & 4 & 5 \\
\hline Switzerland & 5 & 2 \\
\hline Denmark & 6 & 7 \\
\hline UAE & 7 & 10 \\
\hline Norway & 8 & 11 \\
\hline Sweden & 9 & 9 \\
\hline Canada & 10 & 12 \\
\hline Luxembourg & 11 & 8 \\
\hline Ireland & 12 & 6 \\
\hline China Mainland & 13 & 18 \\
\hline Qatar & 14 & 17 \\
\hline Germany & 15 & 13 \\
\hline Finland & 16 & 15 \\
\hline Taiwan & 17 & 14 \\
\hline Austria & 18 & 25 \\
\hline Australia & 19 & 21 \\
\hline United Kingdom & 20 & 19 \\
\hline Israel & 21 & 22 \\
\hline Malaysia & 22 & 24 \\
\hline New Zealand & 23 & 16 \\
\hline Iceland & 24 & 20 \\
\hline & & \\
\hline
\end{tabular}




\begin{tabular}{|c|c|c|}
\hline Country & Position in 2018 ranking & Position in 2017 ranking \\
\hline Japan & 25 & 26 \\
\hline Belgium & 26 & 23 \\
\hline South Korea. & 27 & 29 \\
\hline France & 28 & 31 \\
\hline Czech Republic & 29 & 28 \\
\hline Thailand & 30 & 27 \\
\hline Estonia & 31 & 30 \\
\hline Lithuania & 32 & 33 \\
\hline Portugal & 33 & 39 \\
\hline Poland & 34 & 38 \\
\hline Chile & 35 & 35 \\
\hline Spain & 36 & 34 \\
\hline Slovenia & 37 & 43 \\
\hline Kazakhstan & 38 & 32 \\
\hline Saudi Arabia & 39 & 36 \\
\hline Latvia & 40 & 40 \\
\hline Cyprus & 41 & 37 \\
\hline Italy & 42 & 44 \\
\hline Indonesia & 43 & 42 \\
\hline India & 44 & 45 \\
\hline Russia & 45 & 46 \\
\hline Turkey & 46 & 47 \\
\hline Hungary & 47 & 52 \\
\hline Bulgaria & 48 & 49 \\
\hline Romania & 49 & 50 \\
\hline Philippines & 50 & 41 \\
\hline Mexico & 51 & 48 \\
\hline Jordan & 52 & 56 \\
\hline South Africa & 53 & 53 \\
\hline Peru & 54 & 55 \\
\hline Slovakia & 55 & 51 \\
\hline Argentina & 56 & 58 \\
\hline Greece & 57 & 57 \\
\hline Colombia & 58 & 54 \\
\hline Ukraine & 59 & 60 \\
\hline Brazil & 60 & 61 \\
\hline Croatia & 61 & 59 \\
\hline Mongolia & 62 & 62 \\
\hline Venezuela & 63 & 63 \\
\hline
\end{tabular}

Note: The IMD World Competitiveness Ranking presents the 2018 overall ranking for the 63 economies covered by the WCY. The economies are ranked from the most to the least competitive.

Source: Own elaboration based on the 2018 IMD World Competitiveness ranking, https://www.imd. org/globalassets/wcc/docs/release-2018/ranking2018.pdf 
It should also be emphasized that in this last global competitiveness ranking from the IMD, Poland was ranked $16^{\text {th }}$ among the EU Member States and only $3 \mathrm{EU}$ countries from Central and Eastern Europe overtook Poland: the Czech Republic (29 ${ }^{\text {th }}$ place in the world), Estonia $\left(31^{\text {st }}\right)$ and Lithuania $\left(33^{\text {rd }}\right)$.

On the other hand, Poland's position in world exports in the period 1990-2015 was as follows: in 1990 Poland's share in global export was $0.4 \%$, in $2000-0.5 \%$, in 2005 it was $0.8 \%$, and in $2010,2015,2016$ and 2017 it increased to $1.0 \%, 1.18 \%, 1.19 \%$ and $1.26 \%$, respectively. ${ }^{18}$

Among the most important internal conditions of Poland's foreign trade exchange in 2017, we should mention:

- The fastest economic growth since 2011.

According to the preliminary estimates of the Central Statistical Office (GUS), the Polish GDP in 2017 was higher by $4.6 \%$ in real terms (data in constant prices of the previous year) compared to an increase of $2.9 \%$ in 2016, and in 2018 it may exceed 5\%. Poland remained at the forefront of the EU countries in terms of GDP growth, which was twice as high as the EU average. Domestic demand in 2017 increased by $4.9 \%$ in real terms, total consumption by $4.3 \%$, of which the consumption in the household sector increased by $4.8 \%$ - the highest growth since 2008. A positive result was also recorded in outlays on fixed assets, which - after a strong decline in 2016 - increased in 2017 by $5.2 \%$.

\section{- Favorable trends in the labor market.}

According to the Central Statistical Office, the unemployment rate in Poland at the end of 2017 was $6.6 \%$. In comparison to the previous year, it was a decrease of 1.6 percentage points, and at the same time, it was the lowest level since 1989. At the end of December, about 1.08 million people were jobless, and in the whole of 2017 , the number of unemployed fell by 252,100 people, i.e., by $18.9 \%$. In December 2017, the average employment in the enterprise sector amounted to $6,064,800$ people, and it was higher by $4.6 \% \mathrm{y} / \mathrm{y}$. The average nominal gross monthly salary amounted to PLN $4,973.73$, and it was higher by $7.3 \% \mathrm{y} / \mathrm{y}$. The data refer to entities employing more than nine people.

- The best average PMI value ${ }^{19}$ since 2006.

In December 2017, the PMI index for industry in Poland was 55 points, compared to 54.2 in November - it was the best result in nearly three years. Production volume, employment level and the total number of new orders grew at a faster pace. The number of total new orders reached the fastest growth rate since February 2015, thus extending the growth period to 39 months (the longest sequence of positive readings since the beginning of the survey in June 1998). The

18 Own calculations based on: UNCTAD HANDBOOK of STATISTICS 2016, UNITED NATIONS, New, York and Geneva, 2016, 2017, pp. 2, 8.

19 Purchasing Managers' Index, PMI - a financial activity indicator created by Market Group and Institute for Supply Management of financial activity. It aims to reflect the activity of managers acquiring various types of goods and services. 
average PMI value in the whole of 2017 was 53.6. This is the best annual average since 2006 and the second-best indicator in history.

- Strengthening of the zloty exchange rate, which improved the profitability of imports.

- Polish foreign trade in 2017 reached an exceptionally high value, i.e., over EUR 405 billion, and the growth rate of both streams of trade was the fastest since 2011. ${ }^{20}$

Polish commodity turnover with foreign countries in 2017 reached an exceptionally high value (over EUR 405 billion), which was a result of a dynamic, two-digit growth rate. Exports amounted to EUR 203.7 billion and was higher than the year before by $10.2 \%$; imports equaled EUR 203.3 billion, which means an increase of $12.3 \%$. Like the last two years, the trade balance was positive and amounted to over EUR 0.4 billion in 2017. The higher growth of imports resulted from several factors, including continued strong consumer demand, recovery in investments, an increase in oil prices and the appreciation of the zloty.

Table 2. Goods turnover with foreign countries in 2017

\begin{tabular}{|l|c|c|c|c|c|}
\cline { 2 - 6 } \multicolumn{1}{c|}{} & \multicolumn{3}{c|}{ Value } & \multicolumn{2}{c|}{ Dynamics $(y / y), \%$} \\
\cline { 2 - 6 } & export & import & balance & export & import \\
\hline EUR million & 203,689 & 203,251 & 438 & 110.2 & 112.3 \\
\hline USD million & 228,182 & 227,774 & 408 & 111.3 & 113.5 \\
\hline PLN million & 870,055 & 868,039 & 2,016 & 108.3 & 110.4 \\
\hline
\end{tabular}

Source: Calculations based on statistics from Insigos, Ministry of Entrepreneur.ship and Technology (according to preliminary data of the Central Statistical Office).

\section{Geographical structure of exports}

The list of the five most important export markets in 2017 included: Germany $-27.4 \%$ share in exports, the Czech Republic - $6.4 \%$ (one position higher in relation to 2016), Great Britain - 6.4\% (1 position lower), France - 5.6\% and Italy - almost $5 \%$. The list of the five most important suppliers of goods to Poland in 2017 was the same as in 2016, i.e.: Germany - approx. 23\% share, China-- approx. $12 \%$, Russia $-6.5 \%$, Italy $-5.3 \%$, France - approx. $4 \%$.

Exports to the entire European Union increased by 10\% (to EUR 162.4 billion), of which: to Germany by over $10 \%$, to the Czech Republic by approx.7.5\%, to Great Britain by $5.5 \%$, to France by $12.5 \%$ and to Italy by approx. $13.5 \%$. The EU share in total Polish exports amounted to $80 \%$. Exports to other economically developed countries (outside the EU) increased by approx. 13.5\% (to EUR 13.6 billion), of which: to the

20 Based on Ocena sytuacji w handlu zagranicznym Polski w 2017 r, Ministry of Entrepreneurship and Technology, Warsaw, 2017. 
USA by approx. $27 \%$, to Norway by about $6.5 \%$ and to Switzerland by $12 \%$. The share of this group of markets in the total Polish exports was 6.7\%, compared to 6.5\% in 2016. Export to the CIS countries increased by about 19\% (to EUR 12.6 billion), of which: to Russia by $18.5 \%$, to Ukraine by about $23 \%$ and to Belarus by nearly $8.5 \%$. The share of CIS countries in Polish exports increased by 0.5 percentage points, to $6.2 \%$. Unfortunately, exports to other less developed and developing non-CIS markets in 2017 increased by only $2.6 \%$ (to approx. EUR 15.1 billion). The dynamics of exports to individual markets of this group was distributed very unevenly. A rapid growth of exports was observed in the case of sales to China (by approx. 19\%), Serbia (by almost 16\%) and Mexico (by approx. 26\%). A slow growth of sales was observed in the case of Poland's main export market in this group - Turkey (by approx. 3.5\%), and in the case of some major countries, a decrease was recorded, of which: to Saudi Arabia (by about 13.5\%) and the United Arab Emirates (by approx.17.20\%). ${ }^{21}$

Approximately 55\% of Polish exports in 2017 went to 6 European countries (Germany, the Czech Republic, the United Kingdom, France, Italy and the Netherlands), another ca. 26\% - to the markets of 11 European and non-European countries such as Russia, Sweden, Spain, USA, Hungary, Slovakia, Belgium, Ukraine, Austria, Romania and Denmark. A favorable tendency was the diversification of Polish exports, which have been the growing since 2016 and continued in 2017, which has been visible especially in the markets of non-EU developed countries (along with a simultaneous increase in exports to EU countries). Exports to other economically developed countries (outside the EU) increased by about 13.5\% (to EUR 13.6 billion), of which: to the US by approx. $27 \%$, to Norway by about $6.5 \%$ and to Switzerland by $12 \%$. The rapid growth of exports was also reported in the case of China (by approx. 19\%), Serbia (by almost 16\%) and Mexico (by approx. $26 \%){ }^{22}$

\section{The commodity structure of exports}

The most important commodities in Polish exports in 2017 included: machinery and mechanical appliances and electrical equipment and their parts and accessories thereof (about 24\% share in total exports), vehicles and their parts and accessories thereof (nearly 12\%), furniture (4.8\%), plastics and articles thereof (4.8\%) and articles of cast iron and steel (3.2\%). Technologically advanced goods accounted for $8.6 \%$ of total Polish exports in 2017.

21 Based on: Ocena sytuacji w handlu zagranicznym Polski w 2017 r, MPiT, Warsaw, 2017.

22 Wysokinska Z., RAPORT z realizacji polityki ukierunkowanej na zwiększenie Ekspansji Eksportowej Polski w roku 2017 w ramach STRATEGII NA RZECZ ODPOWIEDZIALNEGO ROZWOJU do roku 2020 (z perspektywa do 2030 r.), unpublished text - elaboration prepared for the Department of Trade and International Cooperation in the Ministry of Entrepreneurship and Technology. 
The Polish trade exchange with foreign countries most often takes the form of intra-industry and intra-firm trade. ${ }^{23}$ Therefore, the commodity structure of imports is similar to that of exports. In 2017, the most important were: mechanical appliances and electrical equipment and their parts and accessories thereof (about $24 \%$ share), vehicles and their parts and accessories thereof (9.7\%), mineral fuels (about 7\%), plastics and articles thereof (about 6\%) and iron, cast iron and steel (approx. 4\%).

A positive trend of high and growing dynamics of exports of more-processed products and technology-intensive goods was recorded in 2017 compared to previous years. The most important product groups in exports were: pharmaceutical products (index of dynamics 148\%), locomotives, rolling stock, track fixtures and fittings, signaling devices (dynamics index of 148\%), optical, photographic, cinematographic, measuring, checking, precision, medical or surgical instruments and apparatus and parts and accessories thereof (dynamics index 132\%). In addition, 10 product groups recorded high export dynamics exceeding $119-131 \%$, and more than 40 product groups achieved positive export dynamics rates exceeding $101-118 \% .^{24}$

\section{Conclusions}

In view of the balanced forecasts regarding the development of the global economy presented by four global organizations, it can be concluded that economic prospects are assessed as moderately good, but not yet sufficient to permanently improve the well-being and the sentiment of the community. The most optimistic economic growth forecasts concern the markets of "emerging" economies and developing countries (above 4\% in 2017-2019). A certain optimism also applies to the forecasts for the Polish economy.

International organizations in their reports provide a number of recommendations for governmental and non-governmental institutions. Especially important here are the IMF recommendations regarding:

- Increasing demand where it is too weak, especially in the area of investment, through carefully selected public investment and removing obstacles for private investors. This may contribute to an increase in capital accumulation and the adoption of new technologies.

23 Exchange with foreign countries was to a large extent the intra-industry and intra-firm trade as it was to a large extent realized among parent companies located in highly developed countries (mainly Western Europe) and their branches in Poland (see also previous research results for 1995 and 2014 of the team: Kawecka-Wyrzykowska E., Ambroziak Ł., Molendowski E., Polan W., Intra-Industry Trade of New Member States. Theory and Empirical Evidence, PWN-SGH, Warsaw, 2017, p. 87 - for Sections VI , VII, XII, XVI, XVII and XVIII).

24 Wysokińska Z., RAPORT z realizacji polityki ukierunkowanej na zwiększenie Ekspansji Eksportowej Polski w roku 2017 w ramach STRATEGII NA RZECZ ODPOWIEDZIALNEGO ROZWOJU do roku 2020 (z perspektywa do 2030 r.), unpublished text - elaboration prepared for the Department of Trade and International Cooperation in the Ministry of Entrepreneurship and Technology. 
- Restructuring corporate indebtedness and strengthening banks' balance sheets, which should facilitate entrepreneurs' access (especially in the SME sector) to credit and stimulate investments in physical and intangible capital.

- It is also important to send clear signals regarding future economic policy, in particular fiscal, regulatory and commercial policy, because it will help support investment decisions.

- Stressing the importance of international trade and its positive impact on economic growth (especially of those countries that have lagged behind) is particularly important from the point of view of Poland as a country with long-term deficits in foreign trade and a relatively low share in global exports, in view of the potential opportunities of our economy.

Recognizing the importance of trade policy (including export policy), investment policy and inclusive policies shows the correctness of actions taken in Poland aimed at reducing the excessive income disproportions accumulated over the years and the rightness of actions stimulating domestic demand by eliminating poverty in lower-paid social groups (e.g. the 500 Plus and Apartment Plus programs). It is also a policy that is in line with the goals of not only global organizations, but also with European Union programs, including the Europe 2020 strategy, based on the social inclusion (inclusive growth) of people who are left outside the labor market and who are ready to take up employment on "normal" terms, i.e., to "exit" from the so-called gray zone.

The recommendations of the IMF experts also recognize the positive impact of trade on labor market trends, and they suggest making international trade a driving force for all countries, which should result from an active trade policy that allows for greater profits from international cooperation.

The recommendations presented above also confirm the correctness of making an export expansion policy one of the basic pillars of macroeconomic policy in Poland and focusing on the diversification of exports and investing in scientific research, the development of modern technologies and the increase of high-tech goods export.

In the face of all the above statements, the preliminary effects of the policy of supporting export expansion (observed two years after its introduction) and making it a pillar of economic growth in Poland should be assessed positively.

In its socio-economic policy, Poland complied with the recommendations of experts from globally recognized international institutions, in particular with regard to increasing the dynamics of trade with foreign countries, including the share of more-processed goods (focusing on export expansion and the diversification of imports and exports) as well as in terms of reducing the scale of social exclusion.

Greater export expansion in the future will require the role of e-commerce in access to foreign markets to be increased by creating large Internet platforms and using in this area the huge potential of well-educated Polish IT specialists and foreign students studying in our country.

The good prospects for the global economy for the coming years create such a chance but it requires the use of new technologies and, above all, the elimination of bureau- 
cratic barriers (including the simplification of procedures) as well as removing fiscal, formal and legal obstacles (especially in the area of business law, which is very complicated in Poland) faced by enterprises (especially by the SME sector). These barriers strongly limit the competitive ability of firms in the domestic market as well as in foreign markets.

\section{References}

ASEAN Investment Report 2017. Foreign Direct Investment and Economic Zones in ASEAN, http://asean.org/storage/2017/11/ASEAN-Investment-Report-2017.pdf; (accessed: 16.03.2018).

Digitalization and Trade -A Holistic Policy Approach is Needed - UNCTAD Report 2017; http://unctad.org/en/pages/PublicationWebflyer.aspx?Publicationid =2094 (accessed: 21.04.2018).

Economic Development in Africa Report 2016-Debt Dynamics and Development Finance in Africa,http://unctad.org/en/pages/PublicationWebflyer.aspx? publicationid=1567; http://unctad.org/en/PublicationsLibrary/gdsecidc2017d3_en.pdf (accessed: 5.12.2017). https://www.imf.org/en/ Publications/WEO/ Issues/2017/07/07/world-economic-outlook-update-july-2017 (accessed: 3.11.2018).

https://www.imf.org/en/Publications/WEO/Issues/2017/07/07/world-economic-outlook-update-july-2017.-IMF Annual Report 2017 (accessed: 3.11.2018).

https://www.imf.org/en/Publications/WEO/Issues/2018/03/20/world-economic-outlook-april-2018 (accessed: 6.05.2018).

IMD WORLD COMPETITIVENESS CENTER; https:/www.imd.org/wcc/world-competitiveness-center-rankings/world-competitiveness-ranking-2018/ (accessed: 7.07.2018).

Information Technology Report 2017, Digitalization, Trade and Development, http:// unctad.org/en/PublicationsLibrary/ier2017_en.pdf; (accessed: 6.05.2018).

International Monetary Fund, Annual Report 2017, Promoting Inclusive Growth, https://www.elibrary.imf.org/doc/IMF011/23917-9781475563252/239179781475563252/ Other_formats/Source_PDF/23917-9781484306123.pdf; pp.6-16; (accessed: 3.11.2018).

Kawecka-Wyrzykowska E., Ambroziak Ł., Molendowski E., Polan W. (2017), Intra-Industry Trade of New Member States. Theory and Empirical Evidence, PWN-SGH, Warszawa.

Materiał DSR MR/według danych wstępnych GUS za rok 2017 i danych ostatecznych GUS za rok 2016.

Ocena sytuacji w handlu zagranicznym Polski w roku 2017, Ministerstwo Przedsiębiorczości i Technologii, Warszawa, 2017.

OECD-Economic Outlook, June 2017, OECD, Paris, 2017 (accessed: 29.01.2019).

Rising product digitalization losing trade competitiveness - UNCTAD Report, http:// unctad.org /en/PublicationsLibrary/gdsecidc2017d3_en.pdf (accessed: 8.12.2017).

UNCTAD HANDBOOK of STATISTICS 2016, UNITED NATIONS, New, York and Geneva, 2016 
The World Bank Global Economic Prospect data dostępu: s: Highlights from: Global Outlook: A Fragile Recovery, http://www.worldbank.org/en/publication/global-economic-prospects (accessed: 9.11.2017).

World Investment Report 2017 (WIR 2017); http://unctad.org/en/PublicationsLibrary/ wir2017_en.pdf (accessed: 28.01.2018).

Wysokinska, Z. (2017), Effects of Poland's pro-export policy implementation in the context of the Plan for Responsible Development - preliminary comparative assessment, "Comparative Economic Research. Central And Eastern Europe", Vol. 20, No. 4.

Wysokinska, Z., RAPORT z realizacji polityki ukierunkowanej na zwiększenie Ekspansji Eksportowej Polski w roku 2017 w ramach STRATEGII NA RZECZ ODPOWIEDZIALNEGO ROZWOJU do roku 2020 (z perspektywa do 2030 r.), unpublished text - elaboration prepared for the Department of Trade and International Cooperation in the Ministry of Entrepreneurship and Technology.

\section{Streszczenie}

\section{Efekty polityki ekspansji eksportowej w Polsce w kontekście zaleceń międzynarodowych organizacji o zasięgu globalnym}

Celem artykułu jest prezentacja wyników przeprowadzonej analizy i oceny realizacji jednego z zadań Strategii na rzecz Odpowiedzialnego Rozwoju (SOR) przyjętej w Polsce do roku 2020 (z perspektywą do roku 2030), jakim jest zwiększenie ekspansji zagranicznej Polski.

W artykule podjęto próbę przedstawienia tych wyników w kontekście diagnoz, prognoz oraz rekomendacji (opracowanych przez ekspertów organizacji globalnych) dotyczących zalecanych kierunków polityki makroekonomicznej dla krajów członkowskich takich organizacji jak: Międzynarodowy Fundusz Walutowy, Grupa Banku Światowego, OECD oraz UNCTAD/ONZ w najbliższych latach.

Słowa kluczowe: Strategia na rzecz Odpowiedzialnego Rozwoju, ekspansja zagraniczna Polski, rekomendacje organizacji globalnych, polityka makroekonomiczna 